\title{
Modification of laparoscopic subtotal cholecystectomy
}

\author{
Kuldip Singh • Harish Matta • Prabhdeep Singh Nain • \\ Baljeet Kumar Basra $\cdot$ Raghav Kumar
}

Published online: 18 March 2011

(C) Springer Science+Business Media, LLC 2011

This is in response to an article by Horiuchi et al. [1]. The authors have done a remarkable job in defining the role of laparoscopic subtotal cholecystectomy in the management of difficult cases of acute cholecystitis. They described that in cases where significant difficulty in dissecting the gallbladder from the liver bed was encountered, the gallbladder's posterior wall was left attached to the liver and the mucosa was ablated using cautery. They also mentioned the inability to biopsy the gallbladder as a drawback to the procedure. There is a small but definite risk of gallbladder cancer being found unexpectedly in $0.2-0.8 \%$ of patients who undergo laparoscopic cholecystectomy [2, 3].

At our center we have also been performing laparoscopic subtotal cholecystectomy for complicated cholecystitis with a slight modification. Prior to cauterization of the mucosa, we take multiple biopsies from the remnant gallbladder mucosa. This modification takes care of the nonavailability of tissue for histopathological examination. Despite the low risk of incidentally detected carcinoma of the gallbladder in cholecystectomy specimens, it is still an important issue worth addressing.

Disclosures K. Singh, H. Matta, P. Nain, B. Basra, and R. Kumar have no conflicts of interest or financial ties to disclose.

\section{References}

1. Horiuchi A, Watanabe Y, Doi T, Sato K, Yukumi S, Yoshida M, Yamamoto Y, Sugishita H, Kawachi K (2008) Delayed laparoscopic subtotal cholecystectomy in acute cholecystitis with severe fibrotic adhesions. Surg Endosc 22:2720-2723

2. Ouchi K, Mikuni J, Kakugawa Y, Organizing Committee, the 30th Annual Congress of the Japanese Society of Biliary Surgery (2002) Laparoscopic cholecystectomy for gallbladder carcinoma: results of a Japanese survey of 498 patients. J Hepatobiliary Pancreat Surg 9:256-260

3. Yamamoto H, Hayakawa N, Kitagawa Y, Katohno Y, Sasaya T, Takara D, Nagino M, Nimura Y (2005) Unsuspected gallbladder carcinoma after laparoscopic cholecystectomy. J Hepatobiliary Pancreat Surg 12:391-398
K. Singh · H. Matta · P. S. Nain · B. K. Basra $(\bowtie) \cdot$ R. Kumar

Department of Surgery, Dayanand Medical College and

Hospital, Ludhiana, Punjab 141001, India

e-mail: baljeetbasra@gmail.com

K. Singh

e-mail: dr_kuldip_singh@dmch.edu 